\title{
“Box Box on the Shelve! Tell Me!": The Effects of Adapted Plays on Physical Fitness in Autism Spectrum Disorder
}

\author{
Atike Yilmaz ${ }^{1} \&$ Fatih Mirze $^{1}$ \\ ${ }^{1}$ School of Physical Education and Sport, Muş Alparslan University, Muş, Turkey \\ Correspondence: Atike Yılmaz, School of Physical Education and Sport, Muş Alparslan University, Muş, \\ Turkey. E-mail: a.yilmaz@alparslan.edu.tr
}

Received: November 2, 2019

Accepted: December 5, 2019 Online Published: January 6, 2020

doi:10.5539/jel.v9n1p110

URL: https://doi.org/10.5539/jel.v9n1p110

\begin{abstract}
The purpose of this study is to examine the effects of adapted play activities on physical fitness in individuals with autism spectrum disorder (ASD). In this study, the pretest-posttest design with a single experimental group was used. The sample of the study is comprised of 7 students with 7-13 years of age. In the measurement of physical fitness parameters of children with ASD, height, body weight, flexibility, vertical jump, and right/left hand grasping power tests were performed. SPSS 23.0 program was used. In addition to descriptive statistics, Wilcoxon signed rank test was used in the comparisons of pretest-posttest measurements. According to the findings of the research, among the physical fitness parameters, it was determined that there were statistically significant differences in the flexibility, vertical jumping, right and left-hand grasping power values, while there was statistically no significant difference concerning the body mass index values. We can mention that the obtained findings demonstrate that play activities lesson program has positive impacts on the physical fitness parameters of children with ASD, and it contributes to their motor developments. Additionally, this research study is considered significant since it leads the way for researchers and teachers of this field and it provides an insight for further studies.
\end{abstract}

Keywords: autism spectrum disorder, play, adaptation, physical fitness

\section{Introduction}

According to the book titled Diagnostic and Statistical Manual of Mental Disorders (DSM-5) (2013) published by the American Psychiatric Association (APA), Autism Spectrum Disorder (ASD) is a neurodevelopmental disorder with an early development stage between 0 and 3 years of age (APA, 2013). According to the same source, it manifests itself in inabilities in two areas as persistent disorder in social communication and interaction, and limited-repetitive behavior patterns (repetitive behavior). Inabilities in the areas of social communication and interaction are characterized, in particular, by features such as inability to engage in non-verbal behavior needed in social interaction, inability to improve age-appropriate peer relationships, limitations in sharing success or interests with others and in social emotional behaviors, delay in language and speech development, repetitive language, and games that are not suitable for developmental level. As per the repetitive/obsessive behaviors and limited-repetitive behaviors, they are reported to emerge as behaviors/characteristics such as intense and unusual interest in a particular area, excessive adherence to certain orders and routines, repetitive and self-stimulating behaviors, extraordinary interest towards objects and obsessive characteristics (Kircali-İftar, 2012; Wolkmar, 1991). Additionally, it is rated in three levels based on the intensity of the ASD.

The first level is named as "Requiring support". In children at this level, when necessary support is not provided, discernible inabilities are observed in social communication and interaction. It emerges in the form of difficulty in initiating social interaction and atypical response or failure to react to social attempt efforts of others. The second level consists of individuals who "Require Intensive Support". Children at this level show significant inabilities in their communication skills. They display features such as inability in social communication skills even if support is provided, and initiating limited social interaction or having little or abnormal responses to others. The third level consists of individuals "Requiring a Heavy Level of Support". At this level, certain features are displayed such as severe inability in non-verbal and verbal social communication and interaction, significant disorders in functionality, initiating very limited social interactions, minimal response to social stimuli from others, etc. (APA-DSM-5, 2013). However, the exact causes of the ASD are not known. It is 
reported that many factors can be effective (Jick \& Kaye, 2003; Kim, Han, Lyoo, Min, Kim, \& Renshaw, 2010; Riva \& Giorgi, 2000; Geier, Kern, Garver, Adams, Audhya, \& Nataf, 2009; Windham, 2006; Van Elst, Riedel, \& Maier, 2016). There are various research studies on the causes of the ASD examining certain factors such as genetic and environmental factors (Caubit, Gubellini, Andrieux, Roubertoux, Metwaly, Jacq, ..., Carlier, 2016; Yi, Danko, Botelho, Patzke, Pak, Wernig, \& Südhof, 2016; Kara \& Yilmaz, 2019; Doenyas, 2019; Herbert, 2010), viral infections, metabolic imbalances, and exposure to chemicals (Libbey, Sweeten, McMahon, \& Fujinami, 2005; Hviid, Hansen, Frisch, \& Melbye, 2019; Schmidt, Hansen, Hartiala, Allayee, Schmidt, Tancredi, ... Hertz-Picciotto, 2011; Ashwood, \& Van de Water, 2004; Volkmar \& McPartland, 2014), and studies examining children with ASD and their families (Klin \& Mercadante, 2006; Demirkaya, Aksu, Taş, \& Özgür, 2016; Volkmar \& Wiesner, 2009).

Studies conducted in recent years in the world and in our country demonstrate that there is a growing proportion of children diagnosed with ASD. In a study covering the years 2000 to 2014, it was determined that the number of individuals diagnosed with ASD increased by $6 \%$ to $15 \%$ each year (Baio, 2014; Baio, Wiggins, Christensen, Maenner, Daniels, Warren, \& Dowling, 2018). In addition, according to the data of the American Center for Disease Control and Prevention, the ASD occurs $1 / 68$. It is considered that approximately $1 \%$ of the world's population is ASD (Christensen, Braun, Baio, Bilder, Charles, Constantino, ..., Yeargin-Allsopp MChristens, 2018). It is observed that the number is increasing and OSB treatment approaches are gaining importance. In addition to medical treatments, the importance of providing education and training environments necessary for individuals to integrate into society and to realize their independent life skills is also increasing.

In the training of ASD individuals, the playing skills are taught and teaching through the play method is used. Unlike their normally developing peers, children with ASDs experience significant inadequacies in displaying spontaneous play behavior. It is reported that this is due to the inadequacy of social communication and interaction, which is the main problem of children with ASD, consequently preventing children from being socially accepted (Childress, 2011; Wolfberg \& Schuler, 1999; Vuran, 2007). Play is the universal language of all children. Through play, children connect with the past and prepare for future situations. It is reported that play positively influences the developmental characteristics of individuals with ASD in certain studies (Kurt \& Yurtçu, 2017; Dawson, Rogers, Munson, Smith, Winter, Greenson, ... Varley, 2010; Princiotta, Goldstein, \& Naglieri, 2013; Memari, Panahi, Ranjbar, Moshayedi, Shafii, Kordi, \& Ziaee, 2015). In the method of teaching through physical education and play, certain methods are used such as "expression method", "faultless teaching", "teaching through discrete essays", "teaching through modeling (Show and practice method)", "activity charts", "positive behavior support", "shaping", and "participation". The priority here is to determine the basic interests and needs of children accurately, and in this direction, to make a choice of methods. Because depending on the child's existing performance, sometimes a single method can be used or sometimes certain methods can be used together. In the teaching of functional and basic mobility skills, the child's play with different purposeful play materials contributes positively to the child's development (Tsai \& Lin, 2011; Ozer \& Ozer, 2000; Reid \& Parsons, 2002). In addition, children can develop the ability to express themselves, communicate and interact with their environment through play. Additionally, it was reported that play activities in evidence-based applications in schools are effective in children with ASD (National Autism Center - NAC, 2015).

The aim of educational plays used in physical education courses is to improve motor skills and physical fitness levels in children. Physical fitness is the capacity of work particular to the individual. This capacity depends on one's strength, quickness, endurance, coordination, and interoperability of these features. The level of physical fitness varies depending on the type of work done (Zorba \& Saygin, 2009). In addition, the exercise-based applications are accepted among the promising applications in the NAC report, and it was accepted among the applications on scientific bases by the National Professional Development Center on Autism Spectrum Disorder, NPDC on ASD report. According to the NPDC on ASD (2013), exercise is a method administered to affect the development of physical fitness of ASD-diagnosed students in a positive manner, as well as to reduce inappropriate behavior and increase desired behaviors (Odom, Cox, \& Brock 2013; Waligórska, Kucharczyk, Waligórski, Kuncewicz-Sosnowska, Kalisz, \& Odom, 2019). For these reasons, our study is important both for its contribution to the literature and for providing new insights to the researchers of this field.

In this respect, the aim of the study is to examine the effects of adapted play activities on the physical fitness levels of individuals with autism spectrum disorder.

\section{Method}

\subsection{Research Model}

This research, which examines the effects of the adapted physical education and play activities lesson on the 
physical fitness levels of individuals with autism spectrum disorder (ASD), was designed as a single-group and pretest-posttest method, which is among the quantitative research methods. In this model, the effect of the applied process is tested on a single group. The measurements of the subjects concerning the dependent variable are obtained by using the same measuring tools on the same subjects as pretest before application, and then posttest after application. There is no radnomness and no matching (Büyüköztürk, Çakmak, Akgün, Karadeniz, \& Demirel, 2016).

\subsection{Research Group}

The participants of the study are comprised of 7 students ( 6 males, 1 female) with 7-13 years of age, who had autism spectrum disorder reports and receiving their education at the Special Education School in Muş province at the 2018-2019 academic year.

Table 1. Descriptive analysis results of the participants

\begin{tabular}{llllll}
\hline & N & Min. & Max. & Mean & S.D. \\
\hline Age & 7 & 7.00 & 13.00 & 10.71 & 2.42 \\
Height & 7 & 122.00 & 152.00 & 137.57 & 12.42 \\
Weight & 7 & 27.00 & 51.00 & 40.71 & 10.62 \\
\hline
\end{tabular}

\subsection{Data Collection Tools}

In terms of the measurements of the pyhsical fitness, height, weight, flexibility, vertical jumping, right-hand and left-hand grasping powers were measured. Before the measurements, explanations were made to the students through being a model and physical assistance, and subsequently two measurements were taken from the students, and the higher value was recorded.

\subsubsection{Measurements of Height and Weight}

The measurements of the body weight and height of the students were measured in sportswear without shoes. In the body weight measurements, Oncomed $s c-101$ bascule was used, and measuring tape with $0.1 \mathrm{~cm}$ sensitivity was used in height measurements.

\subsubsection{Sit-Reach Flexibility Test}

The length, width, and height sizes of the sit-reach (flexibility) test stand were $35 \mathrm{~cm}, 45 \mathrm{~cm}$, and $32 \mathrm{~cm}$, respectively. The upper surface of the stand was $45 \mathrm{~cm}$ long and $45 \mathrm{~cm}$ wide. On the upper surface, a ruler of 0 $50 \mathrm{~cm}$ is fixed to have parallel lines with $5-\mathrm{cm}$ intervals in between. During the measurements, the child sat on the floor and leaned straight against the test table with bare foot. The child tilted his/her body forward, and without bending the knees, stretched forward as far as he/she could with the hands in front of the body, gently pushing the ruler forward. He/she waited 1-2 sec at the farthest point he/she could reach without bending forward or backward. The test was repeated twice and the highest value was recorded.

\subsubsection{Vertical Jumping Test}

Vertical jumping performances of the students were measured by using the jumping board. Students were asked to jump as high as they could. The test was applied twice and the best score was recorded.

\subsubsection{Hand Grasping Power Test}

During the measurement of the hand grasping power values of the participants that was employed while the participants were standing, it was determined that their dominant hands were the right hand, and the measurements were employed with the Takei Grip- $d$ hand dynamometer which measures the strength between 0$100 \mathrm{~kg}$. The dynamometer was adjusted to the hands of each child. Keeping his/her straight arm away from the body on its side with an angle of 10-15 degrees from the shoulder, each child was asked to grasp his/her hand with maximum force without touching his/her body. The measurement was applied twice for the left and right hands separately, and the best score was recorded in $\mathrm{kg}$.

\subsection{Data Collection}

The research was conducted within the scope of the 50-min adapted physical education and play activities course applied 2 days a week for 16 weeks. Participants were divided into 2 groups (groups of 4 and 3 people) and play activities were held. The adapted play activities were prepared in line with the curriculum of learning area/sub-learning areas of the Ministry of National Education. Play plans were prepared in the form of target/target-behaviors, teaching methods and techniques, teaching technology and materials, application, 
measurement, and evaluation phases, and the implementation was processed in accordance with these play plans. Initially, the first measurements of physical fitness were taken, and the final measurements were taken at the end of the 16 weeks.

\subsection{Data Analysis}

In the analysis of the data obtained in the research, the SPSS 23.0 program was used. In the analysis of the data, descriptive statistics and normality tests were applied. Since the data did not demonstrate normal distribution, the Wilcoxon Signed Ranks Test was administered, which is among the "non-parametric" tests. The significance level was accepted as 0.05 for the comparisons.

\section{Results}

Table 2. Physical fitness pretest and posttest descriptive analysis results of the participants

\begin{tabular}{lllllll}
\hline Variable & & N & Min. & Max. & Mean & S.D. \\
\hline Flexibility (cm) & Pre & 7 & 12.00 & 28.00 & 18.714 & 6.499 \\
Vertical Jumping (cm) & Post & 7 & 13.00 & 30.00 & 22.142 & 5.928 \\
& Pre & 7 & 2.20 & 8.40 & 4.885 & 2.394 \\
Right hand grasping (kg) & Post & 7 & 4.90 & 14.30 & 8.257 & 3.393 \\
& Pre & 7 & 4.70 & 6.50 & 5.600 & .6806 \\
Left hand grasping (kg) & Post & 7 & 8.60 & 14.20 & 10.828 & 1.854 \\
\multirow{2}{*}{ Body Mass Index (BMI) $\left(\mathbf{k g} / \mathbf{m}^{2}\right)$} & Pre & 7 & 2.70 & 8.00 & 5.414 & 1.600 \\
& Post & 7 & 3.90 & 11.40 & 8.785 & 2.539 \\
& Pre & 7 & 18.14 & 26.40 & 21.160 & 2.986 \\
\hline
\end{tabular}

Note. Pre $=$ Before the implementation; Post $=$ After the implementation.

Table 3. Pretest and posttest Wilcoxon test results of the participants concerning their flexibility

\begin{tabular}{llllll}
\hline $\begin{array}{l}\text { Post Flexibility } \\
\text { Pre Flexibility }(\mathbf{c m})\end{array}$ & N & Rank mean & Rank total & Z & p \\
\hline Negative rank & 0 & .00 & .00 & -2.375 & $.018^{*}$ \\
Positive rank & 7 & 4.00 & 28.00 & & \\
Equal & 0 & & & & \\
\hline
\end{tabular}

Note. $* \mathrm{P}<0.05 ; \mathrm{N}(6)(\mathrm{Pre}=$ Before the implementation) (Post $=$ After the implementation).

Based on the analysis results shown in Table 3, it was determined that there were statistically significant differences between the pretest and posttest values of flexibility $(\mathrm{z}=-2.375 . \mathrm{p}<0.05)$

Table 4. Pretest and posttest Wilcoxon test results of the participants concerning their vertical jumping

\begin{tabular}{llllll}
\hline $\begin{array}{l}\text { Post Vertical Jumping } \\
\text { Pre Vertical Jumping (cm) }\end{array}$ & N & Rank mean & Rank total & Z & p \\
\hline Negative rank & 1 & 1.00 & 1.00 & -2.197 & $.028^{*}$ \\
Positive rank & 6 & 4.50 & 27.00 & & \\
Equal & 0 & & & & \\
\hline
\end{tabular}

Note. $* \mathrm{P}<0.05 ; \mathrm{N}(6)(\operatorname{Pre}=$ Before the implementation) $(\mathrm{Post}=$ After the implementation).

Based on the analysis results shown in Table 4, it was determined that there were statistically significant differences between the pretest and posttest values of vertical jumping $(z=-2.197 . p<0.05)$

Table 5. Pretest and posttest Wilcoxon test results of the participants concerning their Right Hand

\begin{tabular}{llllll}
\hline $\begin{array}{l}\text { Post Right Hand } \\
\text { Pre Right Hand (kg) }\end{array}$ & $\mathbf{N}$ & Rank mean & Rank total & $\mathbf{Z}$ & $\mathbf{P}$ \\
\hline Negative rank & 0 & .00 & .00 & -2.366 & $.018^{*}$ \\
$\begin{array}{l}\text { Positive rank } \\
\text { Equal }\end{array}$ & 7 & 4.00 & 28.00 & & \\
\hline
\end{tabular}

Note. $* \mathrm{P}<0.05 ; \mathrm{N}(6)(\mathrm{Pre}=$ Before the implementation) (Post $=$ After the implementation). 
Based on the analysis results shown in Table 5, it was determined that there were statistically significant differences between the pretest and posttest values of right (dominant) hand grasping power $(z=-2.366 . p<0.05)$

Table 6. Pretest and posttest Wilcoxon test results of the participants concerning their Left Hand

\begin{tabular}{llllll}
\hline $\begin{array}{l}\text { Post Left Hand } \\
\text { Pre Left Hand (kg) }\end{array}$ & N & Rank mean & Rank total & Z & P \\
\hline Negative rank & 1 & 2.00 & 2.00 & -2.028 & $.043^{*}$ \\
Positive rank & 6 & 4.33 & 26.00 & & \\
Equal & 0 & & & & \\
\hline
\end{tabular}

Note. $* \mathrm{P}<0.05 ; \mathrm{N}(6)(\mathrm{Pre}=$ Before the implementation) (Post $=$ After the implementation).

Based on the analysis results shown in Table 6, it was determined that there were statistically significant differences between the pretest and posttest values of left-hand grasping power $(z=-2.028 . p<0.05)$ level.

Table 7. Pretest and posttest Wilcoxon test results of the participants concerning their Bmi $(\mathrm{kg} / \mathrm{m} 2)$

\begin{tabular}{llllll}
\hline $\begin{array}{l}\text { Post Bmi (kg/m2) } \\
\text { Pre Bmi }\left(\mathbf{k g} / \mathbf{m}^{\mathbf{2}}\right)\end{array}$ & $\mathbf{N}$ & Rank mean & Rank total & $\mathbf{Z}$ & $\mathbf{p}$ \\
\hline Negative rank & 6 & 4.17 & 25.00 & -1.859 & .063 \\
$\begin{array}{l}\text { Positive rank } \\
\text { Equal }\end{array}$ & 1 & 3.00 & 3.00 & & \\
\hline (6) (Pre = Before the implementation) (Post = After the implementation) &
\end{tabular}

Note. ${ }^{*} \mathrm{P}<0.05 ; \mathrm{N}(6)(\mathrm{Pre}=$ Before the implementation $)(\mathrm{Post}=$ After the implementation).

Based on the analysis results shown in Table 7, it was determined that there was statistically no significant difference between the pretest and posttest values of the BMI levels $(z=-1.859 . p>0.05)$.

\section{Discussion and Conclusion}

This study was conducted to examine the effects of adapted play activities on the physical fitness of individuals with ASD. In the literature, there are numerous studies reporting that physical activities have positive effects on the development areas of individuals with ASD (Ganz \& Flores, 2008; Watkins, O'Reilly, Kuhn, \& Ledbetter-Cho, 2019; Blanc, Adrien, Roux, \& Barthélémy, 2005; Jung, \& Sainato, 2015; Jung \& Sainato, 2013). However, this study primarily focused on the effect of the adapted play on physical fitness. In the research findings, it was determined that there were statistically significant differences between the pretest and posttest values of the participant students with autism spectrum disorder concerning flexibility $(\mathrm{z}=-2.375 . \mathrm{p}<0.05)$, vertical jumping $(\mathrm{z}=-2.197 . \mathrm{p}<0.05)$, right (dominant) hand grasping power $(\mathrm{z}=-2.366 . \mathrm{p}<0.05)$, and left-hand grasping power $(\mathrm{z}=-2.028 . \mathrm{p}<0.05)$ levels. However, it was determined that there was statistically no significant difference between the pretest and posttest values of the BMI levels $(\mathrm{z}=-1.859 . \mathrm{p}>0.05)$. In studies on play skills teaching, it was reported that play interventions employed in the adapted environments positively contributed to the development in play skills of children with ASD, increased their social interactions, and reduced negative behaviors (Dauphin, Kinney, \& Stromer, 2004; Hine \& Wolery, 2006). In this context, we can say that the progress in the levels of physical fitness achieved in our study has a positive effect on the social interactions of the participants. In addition, it was also reported that physical activities administered to individuals with ASD had an impact on the development of children's physical fitness and motor skills (Pitetti, Rendoff, Grover, \& Beets, 2007; Lotan, Isakov, \& Merrick, 2004; Yanardağ, Ergun, \& Yılmaz, 2009). Since the findings obtained in our research study increased positively, we can say that the previous studies support our research. In the literature, it is reported that the period of basic is movements is important in the development of motor skills, and by preparing a basis for other body movements, it is extremely important to gain more complex movements (Sarol, 2013). Considering that the students participating in our study are in the period of basic movements, the significance of the study is better understood. Positive results were reported in the literature (Yanardağ, Ergun, \& Yllmaz, 2009; DeBolt, Clinton, \& Ball, 2010; McLaughlin, Byers, \& Vaughn, 2010; Magnusson, Cobham, \& McLeod, 2012; Azar, McKeen, Carr, Sutherland, \& Horton, 2016; Keskin, Hanbay, \& Kalyoncu, 2017; Kara \& Y1lmaz, 2019; Naml, 2011; Yanardağ, 2007). These results support our study. It was determined in our study that there was no statistically significant difference between pretest and posttest levels of body mass index $(\mathrm{z}=-1.859 . \mathrm{p}>0.05)$. We can mention that this result is due to the fact that the play activity studies applied are low-intensity plays. Because the body mass index (BMI) is simply calculated to determine the relationship between height and mass. It is a highly objective criterion that provides information about the nutritional status 
of children and adults (Neyzi, Günöz, Furman, Bundak, Gökçay, \& Darendeliler, 2008). Considering the BMI values of the participant students (mean 20.308), it can be said that the mean weight is ideal in male and female children.

As the conclusion, since the children with ASD have limited opportunities and appropriate play environments and adaptations to develop peer interaction and other critical developmental skills, it can be mentioned that the adapted play activities provided in our study positively influenced the individuals with ASD for the physical fitness levels of children by providing these limited opportunities. In line with these results, it is considered that this study is significant since it guides researchers and teachers, who will work in this field, and provides an insight for further studies. Additionally, in further studies, the effects can be examined by including different groups of disabilities.

\section{References}

American Psychiatric Association. (2013). Diagnostic and Statistical Manual of Mental Disorders (5th ed., DSM-5). Washington, DC.

Ashwood, P., \& Van de Water, J. (2004). A review of autism and the immune response. Journal of Immunology Research, 11(2), 165-174. https://doi.org/10.1080/10446670410001722096

Azar, N. R., McKeen, P., Carr, K., Sutherland, C. A., \& Horton, S. (2016). Impact of motor skills training in adults with autism spectrum disorder and an intellectual disability. Journal on Developmental Disabilities, 22(1), 28.

Baio, J. (2014). Prevalence of autism spectrum disorder among children aged 8 years-autism and developmental disabilities monitoring network. 11 sites, United States, 2010.

Baio, J., Wiggins, L., Christensen, D. L., Maenner, M. J., Daniels, J., Warren, Z., \& Dowling, N. F. (2018). Prevalence of autism spectrum disorder among children aged 8 years - autism and developmental disabilities monitoring network, 11 sites, United States, 2014. MMWR Surveillance Summaries, 67(6), 1-23, https://doi.org/10.15585/mmwr.ss6706a1

Blanc, R., Adrien, J. L., Roux, S., \& Barthélémy, C. (2005). Dysregulation of pretend play and communication development in children with autism. Autism, 9(3), 229-245. https://doi.org/10.1177/1362361305053253

Büyüköztürk, Ş., Çakmak, E. K., Akgün, Ö. E., Karadeniz, Ş., \& Demirel, F. (2016). Scıentıfic research methods. Ankara: Pegem.

Caubit, X., Gubellini, P., Andrieux, J., Roubertoux, P. L., Metwaly, M., Jacq, B., ... \& Carlier, M. (2016). TSHZ3 deletion causes an autism syndrome and defects in cortical projection neurons. Nature Genetics, 48(11), 1359. https://doi.org/10.1038/ng.3681

Childress, D. C. (2011). Play behaviors of parents and their young children with disabilities. Topics in Early Childhood Special Education, 31(2), 112-120. https://doi.org/10.1177/0271121410390526

Christensen, D. L., Braun, K. V. N., Baio, J., Bilder, D., Charles, J., Constantino, J. N., ... Yeargin-Allsopp, M. (2018). Prevalence and Characteristics of Autism Spectrum Disorder Among Children Aged 8 Years Autism and Developmental Disabilities Monitoring Network, 11 Sites, United States, 2012. Morbidity and mortality weekly report. Surveillance Summaries, 65(13), 1-23. https://doi.org/10.15585/mmwr.ss6513a1

Dauphin, M., Kinney, E. M., \& Stromer, R. (2004). Using video-enhanced activity schedules and matrix training to teach sociodramatic play to a child with autism. Journal of Positive Behavior Interventions, 6, 238-250. https://doi.org/10.1177/10983007040060040501

Dawson, G., Rogers, S., Munson, J., Smith, M., Winter, J., Greenson, J., ... Varley, J. (2010). Randomized, controlled trial of an intervention for toddlers with autism: the Early Start Denver Model. Pediatrics, 125(1), e17-e23. https://doi.org/10.1542/peds.2009-0958

DeBolt, L. S., Clinton, E. A., \& Ball, A. (2010). The effects of an adapted physical education program on children with autism: A case study. Kentucky Newsletter for Health, Physical Education, Recreation \& Dance, 47(1), 24-27.

Demirkaya, S. K., Aksu, H., Taş, K., \& Özgür, B. G. (2016). Evaluation of the relationship between the season of birth and neurodevelopmental psychiatric disorders. SDU Medical Faculty Journal, 23(3).

Doenyas, C. (2019). Gut Microbiota as the Mechanism Enabling the Effects of Environment and Diet on Autism. Turk Mikrobiyol Cem Derg., 49(3), 113-117. https://doi.org/10.5222/TMCD.2019.113 
Ganz, J. B., \& Flores, M. M. (2008). Effects of the use of visual strategies in play groups for children with autism spectrum disorders and their peers. Journal of Autism and Developmental Disorders, 38(5), 926-940. https://doi.org/10.1007/s10803-007-0463-4

Geier, D. A., Kern, J. K., Garver, C. R., Adams, J. B., Audhya, T., \& Nataf, R. (2009). Biomarkers of environmental toxicity and susceptibility in autism. Journal of the Neurological Sciences, 280(1-2), 101108. https://doi.org/10.1016/j.jns.2008.08.021

Herbert, M. R. (2010). Contributions of the environment and environmentally vulnerable physiology to autism spectrum disorders. Current Opinion in Neurology, 23(2), 103-110. https://doi.org/10.1097/WCO.0b013e328336a01f

Hine, J. F., \& Wolery, M. (2006). Using point-of-view video modeling to teach play to preschoolers with autism. Topics in Early Childhood Special Education, 26, 83-93. https://doi.org/10.1177/02711214060260020301

Hviid, A., Hansen, J. V., Frisch, M., \& Melbye, M. (2019). Measles, mumps, rubella vaccination and autism: A nationwide cohort study. Annals of Internal Medicine, 170(8), 513-520. https://doi.org/10.7326/M18-2101

Jick, H., \& Kaye, J. A. (2003). Epidemiology and possible causes of autism. Pharmacotherapy. The Journal of Human Pharmacology and Drug Therapy, 23(12), 1524-1530. https://doi.org/10.1592/phco.23.15.1524.31955

Jung, S., \& Sainato, D. M. (2013). Teaching play skills to young children with autism. Journal of Intellectual and Developmental Disability, 38(1), 74-90. https://doi.org/10.3109/13668250.2012.732220

Jung, S., \& Sainato, D. M. (2015). Teaching games to young children with autism spectrum disorder using special interests and video modelling. Journal of Intellectual and Developmental Disability, 40(2), 198-212. https://doi.org/10.3109/13668250.2015.1027674

Kara, T., \& Yllmaz, S. (2019). Theory of mind and related factors in parents of children diagnosed with autism spectrum disorders. Turkish Journal of Clinical Psychiatry, 22(2).

Keskin, B., Hanbay, E., \& Kalyoncu, M. (2017). The Effects of Exercise Practices on Sportive Performance in 5-8 Age Group Autistic Children. Istanbul University Journal of Sport Science, 7(2), 50-58.

Kim, S. M., Han, D. H., Lyoo, H. S., Min, K. J., Kim, K. H., \& Renshaw, P. (2010). Exposure to environmental toxins in mothers of children with autism spectrum disorder. Psychiatry Investigation, 7(2), 122-127. https://doi.org/10.4306/pi.2010.7.2.122

Kırcaali-İftar, G. (2012). Overview of autism spectrum disorder. In E. Tekin-İftar (Ed.), Children with autism spectrum disorder and their education (pp. 17-43). Ankara: Vize Publishing.

Klin, A., \& Mercadante, M. T. (2006). Autism and the pervasive developmental disorders. Brazilian Journal of Psychiatry, 28, 1-2.

Kurt, O., \& Yurtçu, A. B. S. (2017). Comprehensive Interventions for Individuals with Autism Spectrum Disorder. Sakarya University Journal of Education, 7(1), 155-182.

Libbey, J. E., Sweeten, T. L., McMahon, W. M., \& Fujinami, R. S. (2005). Autistic disorder and viral infections. Journal of Neurovirology, 11(1), 1-10. https://doi.org/10.1080/13550280590900553

Lotan, M., Isakov, E., \& Merrick, J. (2004). Improving functional skills and physical fitness in children with rett syndrome. J Intellect Disabil Res., 48, 730-735. https://doi.org/10.1111/j.1365-2788.2003.00589.x

Magnusson, J. E., Cobham, C., \& McLeod, R. (2012). Beneficial effects of clinical exercise rehabilitation for children and adolescents with autism spectrum disorder (ASD). Journal of Exercise Physiology Online, 15(2), 71-79.

McLaughlin, C., Byers, R., \& Vaughn, R. P. (2010). Responding to bullying among children with special educational needs and/or disabilities. UK: Anti-Bullying Alliance.

Memari, A. H., Panahi, N., Ranjbar, E., Moshayedi, P., Shafiei, M., Kordi, R., \& Ziaee, V. (2015). Children with Autism Spectrum Disorder and Patterns of Participation in Daily Physical and Play Activities. Neurology Research International, 2015. https://doi.org/10.1155/2015/531906

Naml, S. (2012). Comparison of the behavioral and motoric performances of autistic individuals according to their involvement in sports. Master Thesis, Sakarya University, Institute of Educational Sciences, Sakarya

National Autism Center [NAC]. (2015). Evidence-Based Practice and Autism in the Schools an educator's guide to providing appropriate interventions to students with autism spectrum disorder (2nd ed.). Retrieved from 
file:///C:/Users/acer/Downloads/NACEdManual_2ndEd_FINAL.pdf

Neyzi, O., Günöz, H., Furman, A., Bundak, R., Gökçay, G., \& Darendeliler, F. (2008). Weight, height, head circumference and body mass index references for Turkish children. Journal of Child Health and Diseases, $51(1), 1-14$.

Odom, S. L., Cox, A. W., \& Brock, M. E. (2013). National Professional Development Center on Autism Spectrum Disorders. Implementation science, professional development, and autism spectrum disorders. Exceptional Children, 79(2), 233-251. https://doi.org/10.1177/001440291307900207

Özer, S., \& Özer, K. (2000). Motor Development in Children. Kazancı Kitap A.Ş: İstanbul.

Pitetti, K. H., Rendoff, A. D., Grover, T., \& Beets, M. W. (2007). The efficacy of a 9-month treadmill walking program on the exercise capacity and weight reduction for adolescents with severe autism. Journal of Autism and Developmental Disorders, 37(6), 997-1006. https://doi.org/10.1007/s10803-006-0238-3

Princiotta, D., Goldstein, G. S. S., \& Naglieri, J. A. (2013). Early start Denver model: an intervention for young children with autism spectrum disorders. Interventions for autism spectrum disorders, 55-73. https://doi.org/10.1007/978-1-4614-5301-7_4

Reid, D. H., \& Parsons, M. B. (2002). Facilitating play dates for children with autism and typically developing peers in natural settings: A training manual. Morganton, NC: Habilitative Management Consultants.

Riva, D., \& Giorgi, C. (2000). The cerebellum contributes to higher functions during development: evidence from a series of children surgically treated for posterior fossa tumours. Brain, 123(5), 1051-1061. https://doi.org/10.1093/brain/123.5.1051

Sarol, H. (2013). The effects of adapted recreational physical activity on the life quality of individuals with autism. Master Thesis, Gazi University, Institute of Health Sciences, Ankara.

Schmidt, J. R., Hansen, R. L., Hartiala, J., Allayee, H., Schmidt, L. C., Tancredi, D. J., ... Hertz-Picciotto, I. (2011). Prenatal vitamins, one-carbon metabolism gene variants, and risk for autism. Epidemiology, 22(4), 476-485. https://doi.org/10.1097/EDE.0b013e31821d0e30

Tsai, T. W., \& Lin, M. Y. (2011, September). An application of interactive game for facial expression of the autisms. In International Conference on Technologies for E-Learning and Digital Entertainment (pp. 204211). Springer, Berlin, Heidelberg. https://doi.org/10.1007/978-3-642-23456-9_37

Van Elst, L. T., Riedel, A., \& Maier, S. (2016). Autism as a disorder of altered global functional and structural connectivity. Biological Psychiatry, 79(8), 626-627. https://doi.org/10.1016/j.biopsych.2016.02.003

Volkmar, F. R., \& McPartland, J. C. (2014). From Kanner to DSM-5: autism as an evolving diagnostic concept. Annual Review of Clinical Psychology, 10, 193-212. https://doi.org/10.1146/annurev-clinpsy-032813-153710

Volkmar, F. R., \& Wiesner, L. A. (2009). A practical guide to autism: What every parent, family member, and teacher needs to know. John Wiley \& Sons.

Vuran, S. (2007). Development of social competences. In S. Eripek (Ed.), Inclusion in primary education (pp. 221-242). Eskişehir: Anadolu University Open Education Faculty Publications.

Waligórska, A., Kucharczyk, S., Waligórski, M., Kuncewicz-Sosnowska, K., Kalisz, K., \& Odom, S. L. (2019). National Professional Development Center on Autism Spectrum Disorders (NPDC) model-an integrated model of evidence-based practices for autism spectrum disorder. Psychiatria Polska, 53(4), 753-770. https://doi.org/10.12740/PP/99163

Watkins, L., O’Reilly, M., Kuhn, M., \& Ledbetter - Cho, K. (2019). An interest - based intervention package to increase peer social interaction in young children with autism spectrum disorder. Journal of Applied Behavior Analysis, 52(1), 132-149. https://doi.org/10.1002/jaba.514

Wolfberg, P. J., \& Schuler, A. L. (1999). Fostering peer interaction, imaginative play and spontaneous language in children with autism. Child Language Teaching and Therapy, 15(1), 41-52. https://doi.org/10.1191/026565999667036164

Yanardağ, M., Ergun, N., \& Yılmaz, İ. (2009). Effects of adapted exercise education on physical fitness in children with autism. Turkish Journal of Physiotherapy Rehabilitation, 20(1), 25-31. 
Yi, F., Danko, T., Botelho, S. C., Patzke, C., Pak, C., Wernig, M., \& Südhof, T. C. (2016). Autism-associated SHANK3 haploinsufficiency causes Ih channelopathy in human neurons. Science, 352(6286), aaf2669. https://doi.org/10.1126/science.aaf2669

Zorba, E., \& Saygın, Ö. (2009). Physical activity and physical fitness. Ankara: Inceler Printing House.

\section{Copyrights}

Copyright for this article is retained by the author, with first publication rights granted to the journal.

This is an open-access article distributed under the terms and conditions of the Creative Commons Attribution license (http://creativecommons.org/licenses/by/4.0/). 